KONSTAN
JURNAL FISIKA DAN PENDIDIKAN FISIKA
Volume 4, Nomor 2, Desember 2019
E-ISSN : 2460-9129 dan P-ISSN : 2460-9110
http://jurnalkonstan.ac.id/index.php/jurnal

\title{
PENGARUH MODEL PEMBELAJARAN PROCESS ORIENTED GUIDED INQUIRY LEARNING (POGIL) TERHADAP KEMAMPUAN BERPIKIR KRITIS SISWA PADA MATERI HUKUM ARCHIMEDES
}

\author{
Ediawati Kusuma Devi ${ }^{1{ }^{*}}$, Emi Sulistri ${ }^{1)}$, Haris Rosdianto ${ }^{1)}$ \\ 1) Program Studi Pendidikan Fisika, STKIP Singkawang, Jalan STKIP Kelurahan Naram, \\ Singkawang Utara, Kota Singkawang, Kalimantan Barat, Indonesia
}

\section{Info Artikel \\ Sejarah Artikel: \\ Diterima Oktober 2019 \\ Disetujui Desember 2019 \\ Dipublikasikan Desember 2019}

Kata Kunci:

Model Pembelajaran

POGIL, Kemampuan

Berpikir Kritis, nonequivalent

control group design

\begin{abstract}
Abstrak
Penelitian ini bertujuan untuk mendeskripsikan peningkatan kemampuan berpikir kritis siswa pada materi hukum Archimedes dan pengaruh penerapan model pembelajaran POGIL terhadap kemampuan berpikir kritis siswa pada materi hukum Archimedes. Metode penelitian menggunakan quasy exsperiment dengan desain penelitian nonequivalent control group design. Populasi dalam penelitian ini adalah seluruh siswa kelas VIII SMP Negeri 3 Singkawang. Teknik pengambilan sampel berupa teknik purposive sampling. Instrumen yang digunakan berupa tes kemampuan berpikir kritis berjumlah 10 soal dalam bentuk pilihan ganda beralasan yang telah diuji validitasnya. Hasil data tersebut kemudian dianalisis menggunakan uji $\mathrm{N}$-gain dan uji statistik. Hasil peningkatan kemampuan berpikir kritis siswa kelas eksperimen sebesar 0,60 dalam kategori sedang dan kelas kontrol sebesar 0,22 dalam kategori rendah. Sehingga data yang diperoleh berdistribusi normal dan homogen. Dari hasil perhitungan uji $\mathrm{t}$ dua sampel tidak berkorelasi didapatkan nilai $\mathrm{t}$ hitung > t tabel yaitu 6,797 > 2,045, maka $\mathrm{H}_{\mathrm{a}}$ diterima dan $\mathrm{H}_{0}$ ditolak pada taraf signifikansi $a=0,05$. Sehingga dapat disimpulkan bahwa terdapat pengaruh model pembelajaran POGIL terhadap kemampuan berpikir kritis siswa pada materi hukum Archimedes.
\end{abstract}

(C) 2019 Universitas Islam Negeri Mataram

* Corresponding Author: ediawatikusumadevi@gmail.com

Alamat korespodensi:

Gedung Pasca Sarjana Lantai 3 Kampus 2 UIN Mataram, Jl. Gajah Mada 100 Jempong Mataram, Indonesia

Email: jurnalkonstan@uinmataram.ac.id 


\section{PENDAHULUAN}

Kemampuan berpikir kritis dipandang sebagai proses pembelajaran yang mengembangkan sikap dan persepsi positif, rasional, serta memperluas wawasan pengetahuan. Berpikir kritis merupakan pemikiran yang beralasan dan reflektif dengan memfokuskan bagaimana membuat keputusan mengenai apa yang harus dipercaya dan apa yang harus dilakukan [1]. Dimana siklus pembelajaran yang mengutamakan kemampuan berpikir kritis dapat mendukung tercapainya ketuntasan hasil belajar siswa yang lebih tinggi [2]. Dalam penilaian kemampuan berpikir kritis siswa dapat dilakukan dengan menyajikan gejala nyata dan bagaimana siswa mengambil keputusan terhadap masalah yang diberikan [3]. Aspek kemampuan berpikir kritis yang digunakan pada penelitian ini, yaitu: penafsiran, analisis, evaluasi, kesimpulan, dan penjelasan [4].

Berdasarkan hasil wawancara dengan guru mata pelajaran IPA didapat bahwa siswa kurang aktif selama proses belajar mengajar berlangsung. Selanjutnya peneliti melakukan observasi perihal proses pembelajaran yang dilaksanakan. Guru sudah menggunakan media dalam penjelasan materi, namun lebih banyak dengan menstransfer pengetahuan secara langsung dan latihan soal sebagai penguat konsep. Hal ini diperkuat dengan hasil tes yang diberikan, diperoleh data bahwa siswa memiliki kemampuan berpikir kritis yang rendah.

Salah satu faktor yang mempengaruhi rendahnya pencapaian ranah kemampuan berpikir kritis diduga terkait dengan proses pembelajaran yang belum sepenuhnya melatih kemampuan tersebut. Pengunaan metode pembelajaran di sekolah secara umum masih menekankan pada aspek penerimaan informasi yang mengakibatkan aktivitas siswa terlihat kurang dalam menggali informasi. Dimana guru sebagai satu-satunya sumber pembelajaran (teacher centered) dan siswa hanya mendengarkan penjelasan yang disampaikan oleh guru, mengakibatkan siswa belum mampu mengajukan pertanyaan dan jawaban mengenai konsepkonsep fisika secara kritis [5]. Pembelajaran yang dilakukan kurang bervariasi dan cenderung membuat siswa menjadi kurang tertarik untuk mempelajari fisika [6].

Proses pembelajaran tersebut menyebabkan konsep penting dalam fisika yang seharusnya mengajak siswa untuk berpikir kritis menjadi hilang. Karena hal tersebut maka kegiatan pembelajaran cenderung pasif dan kemampuan berpikir kritis siswa belum digali secara optimal. Dimana siswa masih kesulitan dalam menentukan dan menghubungkan konsep sebagai langkah penyelesaian suatu persoalan [7]. Siswa juga belum mampu membuktikan dalam menunjukkan kebenaran suatu teorema atau pernyataan [8].

Salah satu usaha yang dapat dilakukan dalam mengatasi permasalahan tersebut adalah memperbaiki proses pembelajaran dengan menerapkan model pembelajaran yang efektif dalam mendorong siswa untuk aktif dan terlibat langsung dalam menemukan konsep terkait materi pembelajaran. Model pembelajaran yang sesuai untuk mewujudkan kemampuan berpikir kritis siswa yaitu Process Oriented Guided Inquiry Learning (POGIL). POGIL merupakan model pembelajaran aktif yang mengembangkan pengetahuan, pertanyaan untuk meningkatkan kemampuan berpikir kritis dan analitis, memecahkan masalah, metakognisi, dann tanggung jawab individu. POGIL suatu pendekatan instruksional yang menggabungkan inkuiri terbimbing dan pembelajaran kooperatif 
dimana siswa terlibat aktif dalam proses pembelajaran [9]. Hasil pembelajaran dengan eksperimen terbimbing lebih efektif dalam meningkatkan keterampilan berpikir kritis siswa [10].

Adapun tahap model pembelajaran POGIL meliputi; Tahap Engage, yaitu sebuah isu menarik disajikan, sebuah jawaban dari pertanyaan why. Tujuan pembelajaran dan kriteria keberhasilan didenifisikan; Tahap Elicit, yaitu sebuah pertanyaan atau isu (demonstrasi) disajikan dan siswa memprediksikan jawaban (materi) yang harus dikuasi disajikan; Tahap Explore, yaitu sebuah kasus atau tugas (percobaan) disediakan yang sesuai sumber materi dan siswa mengeksplorasi model atau soal sebagai respon berpikir kritis; Tahap Explain, yaitu siswa diberi pertanyaan yang mengarah pada berpikir kritis untuk mengidentifikasi konsep dan pemahaman konsep akan yang dibangun; Tahap Elaborate, yaitu keterampilan untuk menyelesaikan soal-soal yang mengarah pada aplikasi dan pengetahuan; Tahap Extend, yaitu perluasan konsep dengan pemberian masalah yang memerlukan sintesis dan diaplikasikan ke pengetahuan baru; Tahap Evaluted, yaitu proses pembelajaran dengan penyelesaian dari masalah melalui jawaban pertanyaan yang diintegrasikan dengan konsep dan peforma dinilai [11].

Penerapan pembelajaran POGIL memiliki beberapa kelebihan antara lain: 1) Pembelajaran POGIL memberi ruang bagi siswa untuk aktif dalam belajar secara kooperatif, 2) Siswa terlebih dahulu menyiapkan diri mengenai materi yang akan dipelajari, 3) Merangsang kemampuan berpikir siswa, 4) Meningkatkan aktivitas belajar siswa melalui kegiatan percobaan sehingga siswa dapat bertukar pendapat dan memberi solusi, 5) Mendorong siswa berani tampil di depan kelas untuk mempersentasikan hasil hipotesisnya. Selain memiliki kelebihan model pembelajaran POGIL juga memiliki kelemahan antara lain: 1) Memerlukan waktu yang relatif lama, 2) Pembagian peran siswa tiap kelompok cenderung sulit untuk dilakukan. Oleh karena itu guru sebagai monitoring dan fasilitator sangat diperlukan. Guru harus berupaya mengatur proses pembelajaran dalam mengases performansi siswa baik secara individu maupun kelompok dan siswa dihadapkan dengan beberapa pertanyaan serta penyajian video.

Berdasarkan hasil penelitian sebelumnya mengenai model pembelajaran POGIL menyatakan bahwa pembelajaran POGIL dapat meningkatkan kemampuan berpikir kritis siswa dengan $75 \%$ berkategori sangat kritis, $18,75 \%$ berkategori kritis, dan 6,25\% siswa berkategori cukup kritis [12]. Hal ini didukung oleh penelitian lainnya bahwa dalam pelaksanaan pembelajaran melalui strategi POGIL telah tercapai $100 \%$ sehingga mempengaruhi aktivitas belajar siswa secara keseluruhan dan berkembangnya kemampuan berpikir kritis siswa [13].

Berdasarkan latar belakang tersebut, peneliti tertarik untuk meneliti pengaruh model pembelajaran POGIL terhadap kemampuan berpikir kritis siswa pada materi hukum Archimedes. Sehingga model pembelajaran POGIL dapat digunakan sebagai model alternatif dalam meningkatkan kemampuan berpikir kritis dan dapat diterapkan dalam pembelajaran fisika di sekolah. 


\section{METODE PENELITIAN}

Penelitian dilakukan di SMP Negeri 3 singkawang tahun ajaran 2018/2019 pada semester genap. Metode penelitian yang digunakan yaitu quasy experiment dengan desain penelitian nonequivalent control group design, karena melibatkan dua kelompok yaitu berupa dua kelas yang diberikan perlakuan berbeda. Kelas pertama adalah kelas eksperimen yang diberi perlakuan dengan model Process Oriented Guided Inquiry Learning (POGIL) dan kelas kedua adalah kelas kontrol yang menggunakan metode pembelajaran langsung (konvensional).

Populasi penelitian seluruh siswa kelas VIII yang terdiri atas 6 kelas dengan jumlah siswa sebanyak 189 siswa. Sampel penelitian dipilih sebanyak 60 siswa terbagi atas dua kelompok kelas yaitu kelas eksperimen adalah kelas VIII C dan kelas kontrol adalah kelas VIII A. Dalam pengambilan sampel tersebut menggunakan teknik purposive sampling dengan kriteria kelas VIII C dan kelas VIII A memiliki kemampuan kognitif yang relatif sama rata berdasarkan nilai ratarata ulangan semester ganjil. Variabel bebas dalam penelitian ini adalah penerapan model pembelajaran POGIL, sementara variabel terikatnya adalah kemampuan berpikir kritis dengan aspek penafsiran, analisis, evaluasi, kesimpulan dan penjelasan. Pada pelaksanaan proses pembelajaran teerdapat 3 pertemuan. Pertemuan pertama dengan materi pengertian hukum Archimedes serta penerapan dalam kehidupan sehari-hari; pertemuan kedua dengan materi tenggelam, terapung dan melayang suatu benda dalam fluida dan pertemuan ketiga digunakan untuk membahas ulang soal kemampuan berpikir kritis yang diberikan.

Data yang dikumpulkan menggunakan tes berupa pretest dan posttest sebanyak 10 soal kemampuan berpikir kritis dalam bentuk pilihan ganda beralasan yang sudah divalidasi oleh ahli. Intrumen soal juga sudah diujicobakan dan dianalisis menggunakan uji reliabilitas, daya pembeda dan tingkat kesukaran, sehingga intrumen layak untuk digunakan. Teknik analisis data terhadap data hasil tes menggunakan uji $\mathrm{N}$-gain, uji prasyarat dan uji hipotesis. Uji prasyarat terdiri atas uji normalitas dan uji homogenitas. Sementara uji hipotesis yang digunakan adalah uji t dua sampel tak berkorelasi.

\section{HASIL DAN PEMBAHASAN}

Data hasil perhitungan pretest dan posttest kemampuan berpikir kritis siswa untuk kelas eksperimen yang menerapkan model pembelajaran POGIL dan kelas kontrol menerapkan metode pembelajaran langsung (konvensional) dapat dilihat pada tabel 1.

Tabel 1. Hasil Pretest dan Posttest Kemampuan Berpikir Kritis Siswa

\begin{tabular}{cllllll}
\hline \multirow{2}{*}{ Kelas } & \multirow{2}{*}{ Data } & $\begin{array}{c}\text { Jumlah } \\
\text { Siswa }\end{array}$ & $\begin{array}{c}\text { Nilai } \\
\text { Terendah }\end{array}$ & $\begin{array}{c}\text { Nilai } \\
\text { Tertinggi }\end{array}$ & $\begin{array}{c}\text { Rata- } \\
\text { Rata }\end{array}$ & $\begin{array}{c}\text { Standar } \\
\text { Deviasi }\end{array}$ \\
\hline \multirow{2}{*}{ Eksperimen } & Pretest & 30 & 20 & 70 & 42,30 & 15,22 \\
& Posttest & 30 & 45 & 95 & 76,60 & 13,56 \\
\multirow{3}{*}{ Kontrol } & Pretest & 30 & 20 & 70 & 39,90 & 12,66 \\
& Posttest & 30 & 30 & 80 & 53,20 & 13,10 \\
\hline
\end{tabular}


Berdasarkan tabel 1, nilai rata-rata kelas eksperimen meningkat sebesar 34,30 dan untuk kelas kontrol meningkat sebesar 13,30 serta menunjukkan bahwa nilai rata-rata kelas eksperimen lebih tinggi dari pada kelas kontrol. Sehingga terbukti penerapan model pembelajaran POGIL lebih efektif dalam meningkatkan kemampuan berpikir kritis. Hal ini diperkuat oleh Nugraheni et al bahwa dalam penerapan model pembelajaran POGIL siswa menjadi lebih aktif dalam membangun pengetahuan secara mandiri melalui kegiatan diskusi kelompok serta prestasi belajar yang dicapai siswa semakin baik [14].

Selanjutnya perolehan data pretest dan posttest tersebut dilakukan uji $\mathrm{N}$ gain untuk mengetahui seberapa besar peningkatan kemampuan berpikir kritis. Adapun skor N-gain kemampuan berpikir kritis siswa dapat dilihat pada gambar 1 .

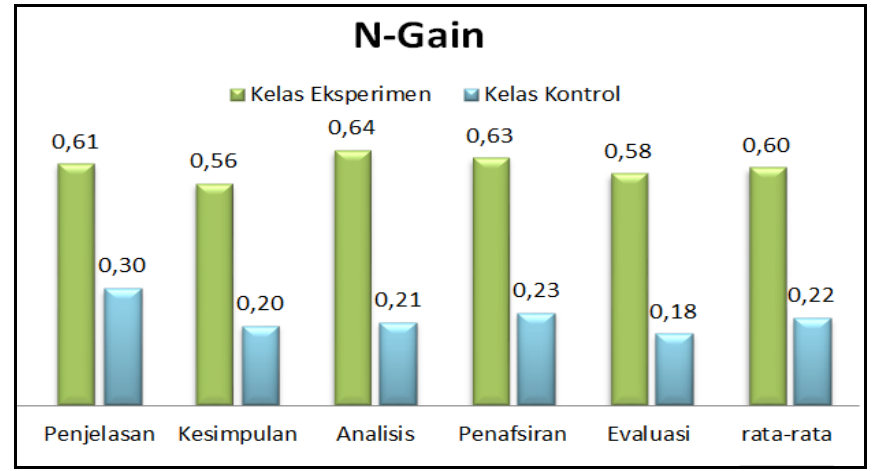

Gambar 1. Skor N-gain Kemampuan Berpikir Kritis

Rerata skor $\mathrm{N}$-gain kelas eksperimen secara keseluruhan sebesar 0,60 dalam kategori sedang dan untuk kelas kontrol rerata skor N-gain sebesar 0,22 dalam kategori rendah. Hal ini dikarenakan kelas eksperimen menerapkan model pembelajaran POGIL yang berkonten pada proses dengan kegiatan percobaan berbantuan lembar kerja siswa (LKS) sehingga siswa turut aktif dalam berhipotesis sesuai fakta yang diperoleh dari pengalaman. Pada tahap pemberian masalah atau kasus terbukti efektif dalam memberikan dampak terhadap peningkatan kemampuan berpikir kritis siswa. Melalui studi kasus siswa mulai belajar membandingkan temuan data, membuat hubungan temuan serta meninjau kembali permasalahan sampai akhirnya dapat membuat sebuah keputusan yang tepat. Sementara kelas kontrol menerapkan metode pembelajaran langsung (konvensional) melalui kegiatan demonstrasi tanpa melibatkan siswa, sehingga kemampuan berpikir siswa kurang terlatih.

Skor N-gain tertinggi pada kelas eksperimen yaitu pada aspek analisis sebesar 0,64. Selama proses pembelajaran siswa dilatih dalam menganalisis suatu permasalahan melalui kegiatan percobaan dan beberapa pertanyaan yang berhubungan dengan pengamatan. Siswa terbiasa untuk memeriksa ide terkait penulisan fakta saat penyelesaian masalah dan informasi diinterpretasikan kebentuk gambar. Dari pengerjaan tersebut siswa mampu memberikan sebuah argumen yang masuk akal serta siswa mampu menghubungkan antara ide atau konsep (strategi penyelesaian) sehingga kemampuan analisis siswa dapat meningkat. Hal ini 
didukung oleh Hilmi et al., bahwa pembelajaran melalui kegiatan percobaan menuntut siswa untuk bisa merangkai alat, mengambil data, mengisi lembar LKS terkait hasil percobaan dan mengolah informasi berdasarkan fakta yang telah diperoleh sehingga kemampuan analisis siswa mengalami peningkatan [15]. Sementara kelas kontrol mendapatkan skor $\mathrm{N}$-gain sebesar 0,21 dalam kategori rendah. Hal ini dikarenakan siswa dan guru secara bersama-sama menganalisis suatu permasalahan dari kegiatan demonstrasi atau melalui media gambar, sehingga siswa belum terbiasa dalam menganalisis untuk memeriksa ide dan mengidentifikasi sebuah argumen.

Sementara kemampuan berpikir kritis pada kelas eksperimen yaitu aspek penjelasan mendapatkan skor N-gain sebesar 0,61. Pada aspek penjelasan mengalami peningkatan karena selama proses pembelajaran siswa ditugaskan dalam mencari konsep sendiri, menghubungkan konsep melalui kegiataan percobaan, dimana guru hanya memantau siswa dan tidak menjelaskan konsep secara rinci. Setelah siswa melakukan penyelidikan terhadap suatu permasalahan siswa dapat menemukan beberapa fakta dari suatu fenomena, sehingga siswa memiliki kemampuan menjelaskan konsep secara mandiri [16]. Sehingga siswa mampu memberikan sebuah penjelasan yang baik melalui proses identifikasi masalah dengan tepat dan sesuai pada konsep yang telah ditemukan. Hal ini diperkuat oleh Maknum et al bahwa saat pembentukan konsep melatih kemampuan berpikir kritis terutama pada aspek penjelasan [17]. Kelas kontrol memperoleh skor N-gain sbesar 0,30 dalam kategori sedang. Aspek penjelasan mendapatkan skor tertinggi diantara aspek kemampuan berpikir kritis lainnya. Hal ini dikarenakan guru menjelaskan konsep secara rinci sehingga siswa tidak mengalami kesulitan dalam mengungkapkan jawaban atas pertanyaan yang diberikan, dengan begitu siswa memiliki kemampuan penjelasan yang baik.

Selanjutnya untuk skor N-gain kelas ekperimen pada aspek kesimpulan sebesar 0,56 dalam kategori sedang. Aspek kesimpulan mendapatkan skor terendah diantara aspek kemampuan berpikir kritis lainnya, dikarenakan kegiatan menyimpulkan lebih sulit dilakukan. Siswa belum terbiasa memecahkan masalah dan membuat kesimpulan yang berkaitan pada hipotesis serta kurang memperhatikan jawaban pertanyaan saat menganalisis data. Hal ini didukung oleh Fahaludin et al bahwa kemampuan yang memiliki nilai terendah yaitu menarik kesimpulan dari hasil kegiatan pembelajaran [18]. Kemampuan aspek kesimpulan dapat dilatihkan setelah pemberian fenomena baru melalui kegiatan praktikum atau percobaan, sehingga siswa terbiasa untuk memprediksi dan mengobservasi yang diakhiri dengan pemaparan hasil penarikan kesimpulan oleh siswa [19]. Sementara kelas kontrol skor $\mathrm{N}$-gain yang diperoleh sebesar 0,20 dalam kategori rendah, karena kegiatan menyimpulkan hanya dilatihkan pada saat proses pembelajaran akan berakhir. Dalam hal ini guru lebih berperan membuat kesimpulan sedangkan siswa lebih terfokus pada pelajaran yang akan segera selesai sehingga siswa belum terampil dan terbiasa saat menyimpulkan konsep yang telah dipelajari.

Pada aspek penafsiran skor N-gain kelas ekperimen sebesar 0,63 dalam kategori sedang. Peningkatan tersebut disebabkan siswa yang sudah terlatih dalam memaknai data yang diperoleh dari hasil percobaan sehingga siswa mampu menafsirkan sesuatu yang telah terjadi. Dimana didukung dengan beberapa pertanyaan dalam LKS sehingga siswa dituntut untuk membuat atau mengubah 
pernyataan kebentuk gambar maupun sebaliknya yang dilengkapi dengan simbol. Proses pembelajaran yang mengkaitkan antara konsep, gambar dan simbol dapat mendukung siswa dalam memahami dan mengembangkan konsepnya, sehingga siswa bisa menerapkan konsep yang telah dipahami dalam situasi nyata atau kejadian dikehidupan sehari-hari [20]. Sementara pada kelas kontrol memperoleh skor $\mathrm{N}$-gain sebesar 0,23 dalam kategori rendah. Kemampuan penafsiran siswa hanya dilatihkan pada saat kegiatan demonstrasi yang mengakibatkan siswa masih bingung dalam memahami konsep dan belum bisa memaknai konsep ketika diberi persoalan terkait gambar.

Aspek evaluasi pada kelas eksperimen dengan skor $\mathrm{N}$-gain sebesar 0,58 dalam kategori sedang. Pada aspek evaluasi mengalami peningkatan dikarenakan siswa dilatih untuk mengevaluasi setiap selesai melakukan kegiatan percobaan dan saat proses pembelajaran akan diakhiri. Siswa ditugaskan membandingkan serta menghubungkan antara hasil percobaan dengan konsep yang telah dipelajari. Hal ini diperkuat oleh Lestari et al kemampuan berpikir kritis pada aspek evaluasi mengalami peningkatan setelah siswa melakukan kegiatan percobaan. Sementara kelas kontrol skor N-gain sebesar 0,18 dalam kategori rendah [21]. Aspek evaluasi memperoleh skor terendah, dikarenakan pada kelas kontrol kemampuan aspek evaluasi tidak dilatihkan.

Tahap selanjutnya analisis data menggunakan uji statistik. Langkah pertama dilakukan uji normalitas yang menggunakan chi kuadrat bertujuan untuk mengukur apakah data tersebut berdistribusi normal. Adapun rekapitulasi hasil uji normalitas pada data pretest dan postets dapat dilihat pada tabel 2 .

Tabel 2. Hasil Uji Normalitas Pretest dan Postest

\begin{tabular}{cccccc}
\hline Kelas & \multicolumn{2}{c}{ Nilai Pretest } & \multicolumn{2}{c}{ Nilai Postest } & \multirow{2}{*}{ Kesimpulan } \\
\cline { 2 - 5 } & $\chi^{2}$ hitung & $\chi^{2}$ tabel & $\chi^{2}$ hitung & $\chi^{2}$ tabel & \\
\hline Eksperimen & 7,571 & 7,815 & 6,284 & 7,815 & Normal \\
Kontrol & 6,144 & 7,815 & 5,745 & 7,815 & Normal \\
\hline
\end{tabular}

Pada Tabel 2 bahwa data hasil pretest dan posttest pada kelas eksperimen dan kelas kontrol diperoleh nilai $\chi^{2}$ hitung $<\chi^{2}$ tabel sehingga data tersebut berdistribusi normal. Langkah kedua yaitu melakukan uji homogenitas dengan membandingkan data pretest dan posttest pada pada kelas eksperimen dan kelas kontrol. Analisis uji homogenitas menggunakan uji barlet bertujuan untuk melihat varian data homogen. Adapun rekapitulasi hasil uji homogen pada data pretest dan postest dapat dilihat pada tabel 3.

Berdasarkan hasil analisis data pretest dan posttest sudah berdistribusi normal dan homogen. Tahap selanjutnya dilakukan uji hipotesis menggunakan uji t-test dua sampel tidak berkorelasi bertujuan untuk mengetahui perbedaan antara kemampuan berpikir kritis siswa kelas eksperimen terhadap kelas kontrol. Rekapitulasi hasil uji t dua sampel tidak berkorelasi dapat dilihat pada tabel 4. 
Tabel 3. Hasi Uji Homogenitas Pretest dan Postets

\begin{tabular}{cccccc}
\hline \multicolumn{1}{c}{ Kelas } & Data & $\mathrm{db}=(\mathrm{n}-1)$ & $\mathrm{S}^{2}$ & $\mathrm{db} \cdot \mathrm{S}^{2}$ & $(\mathrm{db}) \log \mathrm{S}^{2}$ \\
\hline \multirow{2}{*}{ Eksperimen } & Pretest & 29 & 231,73 & 6720.17 & 68,58 \\
& Posttest & 29 & 183,97 & 5335,13 & 65,68 \\
\multirow{2}{*}{ Kontrol } & Pretest & 29 & 160,23 & 4646,67 & 63,94 \\
\multirow{2}{*}{ Jumlah } & Posttest & 29 & 171,68 & 4978,72 & 64,81 \\
$\chi^{2}$ hitung & 4 & 116 & 758,78 & 21680,69 & 263,01 \\
$\chi^{2}$ tabel & & 0,50 & \\
Kesimpulan & & & 7,815 & \\
\hline
\end{tabular}

Berdasarkan tabel 4 diperoleh nilai bahwa t hitung > t tabel yaitu 6,797 > 2,045, maka $\mathrm{H}_{\mathrm{a}}$ diterima dan $\mathrm{H}_{0}$ ditolak pada taraf signifikansi $\alpha=0,05$. Hal ini menunjukkan bahwa terdapat pengaruh model pembelajaran Process Oriented Guided Inquiry Learning (POGIL) terhadap kemampuan berpikir kritis siswa pada materi hukum Archimedes. Penerapan model pembelajaran POGIL dengan metode pembelajaran langsung (konvensional) memiliki pengaruh terhadap kemampuan berpikir kritis siswa. Terlihat dari nilai posttest siswa bahwa nilai rata-rata kelas eksperimen memiliki nilai lebih tinggi dibandingkan kelas kontrol. Hal ini disebabkan karena adanya perbedaan yang mendasar dalam proses pembelajaran, dimana pada model pembelajaran POGIL mengupayakan siswa dapat lebih aktif dan menerima pembelajaran secara langsung serta memunculkan minat siswa terhadap materi yang dipelajari.

Tabel 4. Uji T Dua Sampel Tidak Berkorelasi

\begin{tabular}{ccccc}
\hline Kelas & Rata-Rata & Standar Deviasi (SD) & t hitung & t tabel \\
\hline Eksperimen & 76,60 & 13,56 & \multirow{2}{*}{6,797} & 2,045 \\
\cline { 1 - 3 } Kontrol & 53,20 & 13,10 & & \\
\hline
\end{tabular}

Dimana model pembelajaran POGIL memiliki tahap pembelajaran yang memberikan kesempatan kepada siswa untuk melakukan penyelidikan yang terbagi menjadi tim-tim kecil, melatih siswa dalam menemukan dan menghubungkan suatu konsep, siswa belajar dalam mengungkapkan pendapat, memberikan solusi serta kesulitan selama kegiatan percobaan bisa teratasi. Pemberian masalah dalam pembelajaran membuat siswa tertarik melakukan percobaan secara berkelompok dan melatih kemampuan untuk mengidentifikasi masalah, mengumpulkan data, mengembangkan hipotesis serta mengevaluasi proses dalam penemuan konsep [21]. Sedangkan pada membelajaran metode langsung (konvensional) siswa tidak terlibat langsung dalam menemukan konsep. Siswa dituntut memahami konsep dari membaca buku serta melalui kegiatan demonstrasi yang guru lakukan di depan kelas. 
Hal ini didukung oleh Rahayu \& Pamelasari bahwa pembelajaran melalui model Process Oriented Guided Inquiry Learning (POGIL) memiliki pengaruh yang positif terhadap kemampuan berpikir kritis yang memiliki korelasi sebesar 0,55 dan besarnya kontrisbusi pengaruh model pembelajaran POGIL adalah sebesar 30\% [22]. Hal ini juga diperkuat oleh Rustam et al menyatakan bahwa penerapan model pembelajaran POGIL pada kegiatan mengekplorasi permasalahan berupa pertanyaan yang mengarahkan untuk mengidentifikasi konsep dan pemahaman akan konsep yang dibangun serta aplikasi dari pengetahuan memberi pengaruh yang positif terhadap kemampuan berpikir kritis siswa [23].

\section{SIMPULAN DAN SARAN}

Berdasarkan hasil dan pembahasan yang telah dilakukan dapat disimpulkan terdapat peningkatan kemampuan berpikir kritis siswa setelah diterapkan model pembelajaran POGIL, terlihat dari hasil tes kemampuan berpikir kritis bahwa nilai posttest lebih tinggi bila dibandingkan dengan nilai pretest. Dimana dalam tahap pembelajaran siswa memiliki kesempatan untuk melakukan penyelidikan dalam penemuan konsep. Sehingga terdapat pengaruh diterapkan model pembelajaran POGIL terhadap kemampuan berpikir kritis siswa pada materi hukum Archimedes yang ditunjukkan selama pembelajaran yang menekankan pada proses sehingga siswa terlibat aktif serta memunculkan minat siswa dalam membangun pengetahuan secara mandiri.

Berdasarkan penelitian yang telah dilakukan, dalam penerapan pembelajaran POGIL perlu diperhatikan pembagian peran siswa tiap pertemuan agar setiap kelompok memiliki tanggung jawab yang berbeda, perangkat pembelajaran yang digunakan harus sesuai dengan tahap model pembelajaran POGIL dan pengalokasian waktu dalam proses pembelajaran perlu direncanakan dengan baik.

\section{UCAPAN TERIMA KASIH}

Peneliti mengucapkan banyak terimakasih kepada STKIP Singkawang yang telah memberi fasilitas kepada peneliti, kepala sekolah beserta guru IPA kelas VIII di SMP Negeri 3 Singkawang atas kerjasamanya dalam penyelesaian penelitian ini. Selanjutnya, peneliti ucapkan terimakasih kepada dosen pembimbing yang telah memberi saran dan mengarahkan dalam pembuatan naskah jurnal.

\section{DAFTAR PUSTAKA}

[1] Ennis, R.H. 2013. The Nature of Critical Thinking: Outlines of General Critical Thinking Dispositions and Abilities. Universitas of Illinois, Volume 1, Nomor 1, Hal. 1-8.

[2] Afrizon, R., Wulan, R., \& Fauzhi, A. 2012. Peningkatan Perilaku Berkarakter dan Keterampilan Berpikir Kritis Siswa Kelas IX MTsN Model Padang Pada Mata Pelajaran IPA-Fisika Menggunakan Model Problem Based Instruction. Jurnal Penelitian Pembelajaran Fisika (JPPF), Volume 1, Nomor 1, Hal. 1-12. 
[3] Thompson, C. 2011. Critical Thinking Acros The Curiculum: Process Over Output. International Journal of Humanities and Social Science, Volume 1, Nomor 9, Hal. 1-7.

[4] Facione, P.A. 2013. Critical Thinking: A Statement of Expert Consensus for Purooses of Educational Assessment an Instruction. The Complete American Philosophical Association Delphi Reseach Report, Volume 1, Nomor 1, Hal. 1-19.

[5] Malik, A., Oktaviani, V., \& Handayani, W. 2017. Penerapan Model Process Oriented Guided Inquiry Learning (POGIL) Untuk Meningkatkan Keterampilan Berpikir Kritis Peserta Didik. Jurnal Penelitian \& Pengembangan Pendidikan Fisika (JPPPF), Volume 3, Nomor 2, Hal. 127136.

[6] Sulardi., Nur, M., \& Widodo, H. 2015. Pengembangan Perangkat Pembelajaran Fisika Model Problem Based Learning (PBL) Untuk Melatih Keterampilan Berpikir Kritis Siswa. Pendidikan Sains Pascasarjana Universitas Negeri Surabaya, Volume 5, Nomor 1, Hal. 802-810.

[7] Herniati, R., Sulistri, E., \& Rosdianto, H. 2017. Penerapan Model Predict Observe Explain Dengan Pendekatan Learning By Doing Untuk Meningkatkan Hasil Belajar Siswa. Jurnal Fisika FLUX, Volume 14, Nomor 2, Hal. 120-124.

[8] Kartikasari, D., Medriati, R., \& Purwanto, A. 2018. Penerapan Discovery Learning Model dengan Pendekatan Saintifik untuk Meningkatkan Kemampuan Berpikir Kritis Siswa pada Konsep Kalor dan Perpindahan Kalor. Jurnal Kumparan Fisika, Volume 1, Nomor 2, Hal.1-7.

[9] Purwanto, A., \& Winarti. 2016. Profil Pembelajaran Fisika Dan Kemampuan Berpikir Kritis Siswa Madrasah Aliyah se-DIY. Jurnal Penelitian Pembelajaran Fisika, Volume 7, Nomor 1, Hal. 8-18.

[10] Sen, S., Yilmaz, A., \& Geban, O. 2017. High School Students' Views About Process Oriented Guided Inquiry Learning (POGIL). The Turkish Online Journal of Educational Technology, Volume 3, Nomor 1, Hal. 1114-1119.

[11] Triwiyono. 2011. Program Pembelajaran Fisika Menggunakan Metode Eksperimen Terbimbing Untuk Meningkatkan Keterampilan Berpikir Kritis. Jurnal Pendidikan Fisika Indonesia, Volume 7, Nomor 1, Hal. 80-83.

[12] Hanson, D. M. (2013). Instructor's Guide To Process-Oriented GuidedInquiry Learning. Pacific Crest. Stony Brook University- SUNY

[13] Ningsih, S. M., \& Bambang, S. 2012. Implementasi Model Pembelajaran Process Oriented Guided Inquiry Learning (POGIL) Untuk Meningkatkan Kemampuan Berpikir Kritis Siswa. Unnes Physics Education Journal (UPECJ), Volume 1, Nomor 2, Hal. 44-52.

[14] Rohmah, Y. N., \& Muchlis. 2013. Penerapan Pembelajaran Dengan Strategi POGIL Pada Materi Pokok Kelarutan dan Hasil Kali Kelarutan Untuk Melatih Kemampuan Berpikir Kritis Siswa Kelas XI SMA Negeri 1 Sooko Mojokerto. Unesa Journal of Chemical Education, Volume 2, Nomor 3, Hal. 19-23.

[15] Nugraheni, F., Mastur, Z., \& Wijayanti, K. (2014). Keefektifan Model Process Oriented Guided Inquiry Learning Terhadap Kemampuan Pemecahan 
Masalah. Unnes Journal Of Mathematics Education, Volume 3, Nomor 1, Hal. 1-7.

[16] Hilmi, M., Sunarno, W., \& Saputro, S. 2015. Pembelajaran Kimia Menggunakan Pendekatan Inkuiri Dengan Metode Eksperimen dan Proyek Ditinjau Dari Kreativitas Dan Kemampuan Berpikir Kritis Siswa. Jurnal Inkuiri, Volume 4, Nomor 1, Hal. 92-103.

[17] Solihin, M.W., Prastowo, S.H.B., \& Supeno. 2018. Pengaruh Model Pembelajaran Inkuiri Terbimbing Terhadap Kemampuan Berpikir Kritis Siswa SMA. Jurnal Pembelajaran Fisika, Volume 7, Nomor 3, Hal. 299-306.

[18] Maknum, H. L., Setyarsih, W., \& Rohmawati, L. 2018. Analisis POGIL (Process Oriented Guided Inquiry Learning) Sebagai Model Dalam Melatihkan Keterampilan Berpikir Kritis Siswa SMA. Jurnal Inovasi Pendidikan Fisika, Volume 7, Nomor 2, Hal. 320-324.

[19] Fahaludin, I., Wigati, I., \& Pujiastuti, A. 2016. Pengaruh Model Pembelajaran Inkuiri Terbimbing Terhadap Kemampuan Berpikir Kritis Siswa Pada Pembelajaran Materi Pengelolaan Lingkungan Di SMP Negeri 2 Tanjung Lago, Kabupaten Banyuasin. Jurnal Bioilmi, Volume 2, Nomor 2, Hal. 92-101.

[20] Maulida, R.A.N., Kusumawati, I., \& Wijaya, A.K. 2018. Pengembangan Buku Petunjuk Praktikum IPA Berbasis Model Pembelajaran POE (Predict Observe Explain) Pada Materi Usaha dan Energi. Jurnal Ilmu Pendidikan Fisika (JIPF), Volume 3, Nomor 1, Hal. 14-19.

[21] Lestari, D.A.B., Astuti, B., \& Darsono, T. 2018. Implementasi LKS Dengan Pendekatan STEM (Science, Technology, Engineering, And Mathematics) Untuk Meningkatkan Kemampuan Berpikir Kritis Siswa. Jurnal Pendidikan Fisika dan Teknologi, Volume 4, Nomor 2, Hal. 202-2017.

[22] Rahayu, D. P., \& Pamelasari, S. D. 2015. Pengaruh Model Pembelajaran Process Oriented Guided Inquiry Learning Terhadap Kemampuan Berpikir Kritis Peserta Didik Pada Materi Perubahan Benda. Unnes Science Education Journal, Volume 4, Nomor 3, Hal. 936-944.

[23] Rustam, Ramdani, A., \& Setijani, P. 2017. Pengaruh Model Pembelajaran Process Oriented Guided Inquiry Learning (POGIL) Terhadap Pemahaman Konsep IPA, Keterampilan Proses Sains Dan Kemampuan Berpikir Kritis Siswa SMP Negeri 3 Pringgabaya Lombok Timur. Jurnal Penelitian Pendidikan IPA (JPPIPA), Volume 3, Nomor 2, Hal. 33-41. 